\title{
CHARACTERIZATION OF SUNFLOWER SEED AND KERNEL PROTEINS
}

\author{
Žilić, S. ${ }^{*}$, Barać, M. ${ }^{2}$, Pešić, M. ${ }^{2}$, Crevar, M. ${ }^{1}$, Stanojević, S. ${ }^{2}$, Nišavić, A. ${ }^{1}$, \\ Saratlić, G. ${ }^{1}$, Tolimir, M. ${ }^{1}$ \\ ${ }^{1}$ Maize Research Institute "Zemun Polje“, Slobodana Bajića 1, \\ Belgrade-Zemun, Serbia \\ 2 Faculty of Agriculture, University of Belgrade, Nemanjina 6 , \\ Belgrade-Zemun, Serbia
}

Received: September 5, 2009

Accepted: May 28, 2010

\begin{abstract}
SUMMARY
Total sunflower proteins, storage proteins, and helianthinin (11S) and 2S albumin fractions and their respective subunits in seeds and kernels of three sunflower hybrids were analyzed. Protein contents were analyzed by sodium dodecyl sulfate-polyacrylamide gel electrophoresis (SDS-PAGE) and coupled with densitometry. The SDS-PAGE profiles of the seed and kernel proteins in the crude extracts for all genotypes showed a very similar number of protein bands (thirty two) in the electrophoretograms. Three polypeptide groups of helianthinin fraction were detected. Two of these were acidic ( $\alpha$, $\mathrm{Mw}=36,800-42,900 \mathrm{Da}$ and $\alpha^{\prime}, \mathrm{Mw}=31,000-35,300 \mathrm{Da}$ ), while one was basic $(\beta, \mathrm{Mw}=21,000-29,600 \mathrm{Da})$. The molecular weight of the $2 \mathrm{~S}$ albumin proteins ranged from 11,500 to $20,100 \mathrm{Da}$. According to our results, there were significant differences among the seed and kernel protein contents. The $2 \mathrm{~S}$ albumin content was significantly higher in kernels than in whole seeds of sunflower hybrids $(\mathrm{P}<0.05)$. By contrast, the $11 \mathrm{~S}$ helianthinin content was significantly higher in seeds (where it ranged from 61.75 to $67.70 \%$ of totally extracted proteins) than in kernels (varied from 57.36 to $61.51 \%$ of totally extracted proteins) of sunflower hybrids $(\mathrm{P}<0.05)$.
\end{abstract}

Key words: sunflower, soluble protein fractions and subunits

\section{INTRODUCTION}

The sunflower is one of the four most important oil crops globally and is grown on over 21 million hectares worldwide (Škorić et al., 2007). Seeds of sunflower are mainly used for their oil content, which accounts for $80 \%$ of the value of the sunflower crop. At the same time, there is an increasing interest in the use of sunflower protein (Helianthus annuus L.) in human nutrition. Sunflower seeds contain

* Corresponding author: Phone: +381 3756 704; Fax: +381 3754 994; e-mail: szilic@mrizp.rs 
$\sim 20 \%$ of protein, whereas protein contents of the oil press cakes and extraction residues range from 30 to 50\% (Dorrell and Vick, 1997). The techno-functional properties of sunflower proteins are comparable with those of soy and other leguminous proteins (González-Pérez et al., 2005). Although lysine deficiency is a major drawback from the nutritional point of view, proteins from sunflower press cake are considered a valuable alternative as food ingredients, since they are low in antinutritional compounds and devoid of toxic substances (González-Pérez and Vereijken, 2007). The sunflower protein isolates can be subjected to hydrolytic treatments in order to produce protein hydrolysates that have improved functional and nutritional properties (Villanueva et al., 1999). In addition, protein hydrolysates are also a source of bioactive peptides, which are short peptides and have a certain biological activity that may be beneficial for the organism (Megías et al., 2008). Bioactive peptides with different impacts on the regulation of the gastrointestinal, nervous, cardiovascular and immune systems have been described (Korhonen and Pihlanto, 2006).

Composition and conformation are responsible for a sunflower protein's functionality. Compositional differences that may alter functionality include the ratio of protein fractions, variations in subunit concentrations within fractions, and differences in amino acid profiles. Sunflower proteins have two major salt-extractable fractions (2S, and 11S) that can be isolated on the basis of their sedimentation coefficients. The main storage proteins in sunflower make up about $85 \%$ of the total protein content. The $11 \mathrm{~S}$ helianthinin belongs to the widely distributed legumin-like family of globulins and $2 \mathrm{~S}$ albumins, which, in turn, belong to a larger protein family. The helianthinins are generally considered to be the major group of storage proteins, being reported to account for some $60 \%$ of the total proteins in the mature seed with the 2 S albumins accounting for about 20\% (Kortt and Caldwell, 1990). However, early studies of the salt-soluble proteins by sucrose gradient centrifugation gave different results, with $62 \% 2 \mathrm{~S}$ albumins and $38 \% 11 \mathrm{~S}$ globulins (Youle and Huang, 1981). González-Pérez and Vereijken (2007) reported that globulins constitute most of the sunflower proteins, ranging from about 40 to $90 \%$, while albumins account for about $10-30 \%$ of the total proteins. Glutelins and, in particular, prolamins are only minor fractions. The proportions of proteins with different sedimentation coefficients depend largely on conditions such as type of buffer, $\mathrm{pH}$, ionic strength, chemical, physical or enzymatic modification, etc. (Molina et al., 2001). Therefore, literature data show considerable variation in the proportions of the different protein fractions according to the sedimentation coefficient. Also, sunflower proteins have two small amount salt-extractable fractions (6-9S) and high molecular weight fraction (15-18S). The latter fraction has been described as an aggregate of the 11S fraction (Guéguen et al., 1988). In contrast to soybean globulins, sunflower globulins do not contain any genetically independent 7S constituent (Anisimova and Gavrilyuk, 1990). Nevertheless, various amounts of proteins with 7S sedimentation coefficient have been detected in sunflower seeds (Kabirullah and 
Wills, 1983). These 7S constituents are most likely dissociation products of the $11 \mathrm{~S}$ globulins, a dissociation which also occurs in soybean glycinin. In addition to the storage albumins and globulins, sunflower seeds also accumulate a third group of proteins. These are the oleosins, or oil body proteins, which are associated with the outer surface of the oil bodies and are thought to prevent coalescence (Ross and Murphy, 1992).

Helianthinin has been reported to be present as a globular oligomeric protein with a molecular weight $(\mathrm{Mw})$ of $300-350 \mathrm{kDa}$. The currently most accepted model of helianthinin (11S), at neutral $\mathrm{pH}$, consists of an arrangement of six spherical subunits into a trigonal antiprism (Plietz et al., 1983). The monomeric subunits consist of an acidic (32-44 $\mathrm{kDa}$ ) and a basic (21-27 $\mathrm{kDa}$ ) polypeptide linked by a disulfide bond (Dalgalarrondo et al., 1984). Sunflower albumins are basic proteins with a molecular mass in the 10-18 kDa range (Kortt and Caldwell, 1990). Two types of albumin are distinguished: methionine-rich and methionine-poor albumins. In contrast to $2 \mathrm{~S}$ seed albumins from other species that consist of two chains linked by disulfide bonds, sunflower albumin consist of a single polypeptide chain (Pandya et al., 2000).

Sunflower protein contains low levels of lysine, whereas it is relatively rich in sulphur-containing amino acids compared with other oil seeds (Canibe et al., 1999). These authors reported that the average contents of lysine, threonine, cystine and methionine in twelve sunflower genotypes were $3.72,3.65,1.63$ and 2.33 $\mathrm{g} / 16 \mathrm{gN}$, respectively. Glutamic acid was the amino acid present at the highest concentration ( $19.18 \mathrm{~g} / 16 \mathrm{gN}$ ).

The purpose of the present study was to employ analytical methods to determine differences among investigated sunflower genotypes and whether the analyzed hybrids could be sources of specific proteins. A more detailed knowledge of the variability of protein and protein subunit accumulation among ZP sunflower genotypes could facilitate ongoing efforts to improve both quantity and quality of sunflower protein. Seed storage proteins may be used to determine the cultivar trueness and genetic purity of the sample.

\section{MATERIAL AND METHODS}

\section{Plant material}

The three oilseed hybrids of sunflower (Helianthus annuus L.) selected for this investigation were Es Petunija, Allium and Albatre. All three are adapted to European conditions and have been developed in cooperation between the Maize Research Institute, Zemun Polje, (MRIZP), Serbia and the French agribusiness cooperative Euralis. The three hybrids all have a high yield potential and are characterized by high tolerance to lodging and Phomopsis spp. The hybrid Allium has significant tolerance of Sclerotinia spp, while Albatre, as a stay-green hybrid, is tol- 
erant of drought. Seeds were collected at full maturity from plants grown in a fieldtrial at the MRIZP during the 2009 growing season.

The defatted wholemeal flour (particle size $<500 \mu \mathrm{m}$ ), obtained by grounding sunflower seeds and kernels on a Cyclotec 1093 lab mill (FOSS Tecator, Sweden), was used in the analyses. Defatting was carried out by diethyl ether extraction at $35^{\circ} \mathrm{C}$ in a Soxhlet extractor.

\section{Albumin, globulin, prolamin and glutelin contents}

Different protein fractions were obtained by successive extractions of defatted sunflower flour with a series of solvents (in a ratio 1:10 w/v) according to a modified Landry and Moureaux (1970) method. Distilled water, $0.5 \mathrm{M} \mathrm{NaCl}, 70 \%$ ethanol, and $0.2 \mathrm{M} \mathrm{NaOH}$ were used to extract albumin, globulin, prolamin, and glutelin fractions, respectively. Extraction of each protein fraction was done by repeated stirring tree times for $30 \mathrm{~min}$ at $4^{\circ} \mathrm{C}$, followed by centrifugation at $20,000 \mathrm{~g}$ for 15 min. Protein content was calculated in each fraction from the nitrogen content determined by the micro Kjeldahl method using 5.50 as the conversion factor. The results are given as percentage of dry matter (d.m.) as well as percentage of total protein (protein solubility index-NSI).

\section{Sodium dodecyl sulfate-polyacrilamide gel electrophoresis}

Soluble protein composition of the defatted samples was detected by the sodium dodecyl sulfate-polyacrilamide gel electrophoresis (SDS-PAGE) performed according to Fling and Gregerson (1986) on $12.5 \%$ gel in vertical electrophoretic unit (LKB, Sweden). Defatted flour was extracted for $120 \mathrm{~min}$ at room temperature with Tris- $\mathrm{HCl}$ buffer $\mathrm{pH} 8.0$ in the ratio 1:20 and centrifuged at 17,000 $\mathrm{g}$ for $15 \mathrm{~min}$ (Thanh and Shibasaki, 1976). The protein content in the supernatant was determined according to the method of Bradford (1976) using bovine serum protein (BSA, Sigma, USA) as a standard. Prior to electrophoresis, soluble proteins have been diluted to $2 \mathrm{mg} / \mathrm{cm}^{3}$ with the sample buffer (0.055 M Tris- $\mathrm{HCl}, \mathrm{pH} 6.8,2 \%$ (w/ v) sodium dodecyl sulfate (SDS), $7 \%(\mathrm{v} / \mathrm{v})$ glycerol, $4.3 \%(\mathrm{v} / \mathrm{v}) \beta$-mercaptoethanol, $0.0025 \%(\mathrm{w} / \mathrm{v})$ bromophenol blue), heated at $90^{\circ} \mathrm{C}$ for $5 \mathrm{~min}$ and cooled at room temperature. Twenty five $\mu \mathrm{l}$ sample was loaded per well. Gels were run at $30 \mathrm{~mA}$ for 6 hours, fixed and stained with $0.23 \%(\mathrm{w} / \mathrm{v})$ Coomassie Blue R-250 dissolved in $3.9 \%(\mathrm{w} / \mathrm{v})$ trichloroacetic acid (TCA), $6 \%(\mathrm{v} / \mathrm{v})$ acetic acid and $17 \%(\mathrm{v} / \mathrm{v})$ methanol for 45 min. Destaining was performed with $8 \%$ acetic acid and $18 \%(\mathrm{v} / \mathrm{v})$ ethanol. Molecular weights of the polypeptides were estimated by using low molecular weight standards (Pharmacia, Sweden): phosphorylase B (94.0 kDa), bovine albumin (67.0 $\mathrm{kDa}$ ), ovalbumin (43.0 kDa), carbonic anhydrase (30.0 kDa), soybean trypsin inhibitor $(20.1 \mathrm{kDa})$, and $\alpha$-lactalbumin $(14.4 \mathrm{kDa})$. The protein bands on the destined gel were quantitated using SigmaGel software version 1.1 (Jandal, San Rafael, CA).

The kernel/achene ratios were 3.02, 2.76 and 2.62 in the sunflower hybrids Es Petunija, Allium and Albatre, respectively. However, the content of protein frac- 
tions, subunits and different polypeptides are expressed as percentage of total extracted protein. Therefore, our data are a result of differences among kernel and seed protein, not of kernel to achene ratio.

\section{Statistical analyses}

All chemical analyses were performed in three replicates and the results were statistically analyzed. Significant statistical differences of observed chemical sunflower parameters means were determined by Fisher's least significant difference (LSD) test after the analysis of variance (ANOVA) for trials set up according to the RCB design.

\section{RESULTS AND DISCUSSION}

Sunflower protein applications refer mainly to the fortification of foods by sunflower meal, especially meat and milk products, infant formulae, bakery products, and pasta products.

Data in Table 1 indicate that no significant differences in total protein content were detected among either the seeds or the kernels of the sunflower genotypes analyzed $(\mathrm{P}<0.05)$. The results showed that the total protein content was significantly higher (by about 42\%) in the kernels than in the seeds of the sunflower hybrids studied. The content of total proteins was $25.03,23.84$, and $23.84 \%$ in the seeds and $43.42,43.02$, and $42.73 \%$ in the kernels of the hybrids Es Petunija, Allium and Albatre, respectively.

Table 1: The content of soluble protein fractions in defatted sunflower flour. The results are presented as \% of dry matter (1) and \% of total protein (2)

\begin{tabular}{lccccccccc}
\hline \multirow{2}{*}{ Hybrids } & \multirow{2}{*}{ Protein } & \multicolumn{10}{c}{ Extracting solution } \\
\cline { 2 - 11 } & \multicolumn{1}{c}{ Water } & \multicolumn{1}{c}{$\mathrm{NaCl}$} & $\mathrm{C}_{2} \mathrm{H}_{5} \mathrm{OH}$ & \multicolumn{2}{c}{$\mathrm{NaOH}$} \\
\cline { 2 - 11 } & $(1)$ & $(1)$ & $(2)$ & $(1)$ & $(2)$ & $(1)$ & $(2)$ & $(1)$ & $(2)$ \\
\hline Es Petunia (seed) & $25.03^{\mathrm{c}}$ & $10.98^{\mathrm{d}}$ & $43.87^{\mathrm{a}}$ & $3.08^{\mathrm{d}}$ & $12.30^{\mathrm{e}}$ & $0.24^{\mathrm{b}}$ & $0.96^{\mathrm{bc}}$ & $4.62^{\mathrm{e}}$ & $18.45^{\mathrm{c}}$ \\
Allium (seed) & $23.84^{\mathrm{d}}$ & $9.48^{\mathrm{e}}$ & $39.77^{\mathrm{C}}$ & $3.28^{\mathrm{d}}$ & $13.76^{\mathrm{d}}$ & $0.38^{\mathrm{a}}$ & $1.61^{\mathrm{a}}$ & $5.59^{\mathrm{c}}$ & $23.32^{\mathrm{a}}$ \\
Albarte (seed) & $23.84^{\mathrm{d}}$ & $9.32^{\mathrm{f}}$ & $39.09^{\mathrm{d}}$ & $2.80^{\mathrm{d}}$ & $11.74^{\mathrm{e}}$ & $0.24^{\mathrm{b}}$ & $1.01^{\mathrm{b}}$ & $4.15^{\mathrm{f}}$ & $17.41^{\mathrm{d}}$ \\
Es Petunia (kernel) & $43.43^{\mathrm{a}}$ & $18.60^{\mathrm{a}}$ & $42.83^{\mathrm{b}}$ & $8.75^{\mathrm{c}}$ & $20.14^{\mathrm{c}}$ & $0.36^{\mathrm{a}}$ & $0.77^{\mathrm{C}}$ & $5.35^{\mathrm{d}}$ & $12.32^{\mathrm{f}}$ \\
Allium (kernel) & $43.02^{\mathrm{ab}}$ & $16.58^{\mathrm{c}}$ & $38.52^{\mathrm{e}}$ & $10.7^{\mathrm{a}}$ & $24.87^{\mathrm{a}}$ & $0.34^{\mathrm{a}}$ & $0.84^{\mathrm{bc}}$ & $9.68^{\mathrm{a}}$ & $22.50^{\mathrm{b}}$ \\
Albatre (kernel) & $42.73^{\mathrm{b}}$ & $18.24^{\mathrm{b}}$ & $42.69^{\mathrm{b}}$ & $9.89^{\mathrm{b}}$ & $23.14^{\mathrm{b}}$ & $0.36^{\mathrm{a}}$ & $0.84^{\mathrm{bc}}$ & $7.05^{\mathrm{b}}$ & $16.50^{\mathrm{e}}$ \\
LSD $_{0.05}$ & 0.486 & 0.047 & 0.141 & 0.520 & 0.667 & 0.047 & 0.199 & 0.176 & 0.518 \\
\hline
\end{tabular}

${ }^{a-f}$ Means followed by the same letter within the same row are not significantly different $(P<0.05)$

Water soluble proteins, determined by the Landry and Moureaux (1970) method, were the dominant protein fraction in all the genotypes. The NSI of water soluble proteins was $43.87 \%$ in the whole seed of the hybrid Es Petunija. In the other sunflower samples, the content of water soluble proteins was lower by 2.5$12.2 \%$, ranging from $42.83 \%$ in the kernel of the hybrid Es Petunija to $38.52 \%$ in the kernel of the hybrid Allium (Table 1). The salt soluble protein content was significantly higher in the kernels than in the seeds of the hybrids $(\mathrm{P}<0.05)$. The ker- 
nel of the sunflower Allium had the highest content of salt soluble proteins by a significant margin ( $24.87 \%$ of the total protein content). The lowest content of salt soluble proteins was found in the seed of the hybrid Albatre $(11.74 \%$ of the total protein content). The protein fraction with the lowest NSI (0.77-1.61\%) was soluble in alcohol in all analyzed samples (Table 1). The NSI of base soluble proteins was very high in all analyzed samples and ranged from $16.50 \%$ in the kernel of Albatre to $23.32 \%$ in the seed of Allium. Considering that most water soluble proteins are also soluble in salt solution, the literature notes the helianthinin fraction as the major storage protein component in sunflower that accounts for approximately 40 to $90 \%$ of the total storage proteins in sunflower seed (González-Pérez and Vereijken, 2007).

Table 2: The polypeptides composition in seed and kernel of sunflower hybrids (\% per total soluble proteins)

\begin{tabular}{|c|c|c|c|c|c|c|c|}
\hline \multirow{2}{*}{ Polypeptides } & \multicolumn{3}{|c|}{ Whole seed } & \multicolumn{3}{|c|}{ Kernel } & \multirow{2}{*}{$\operatorname{LSD}_{0.05}$} \\
\hline & Es Petunia & Allium & Albarte & Es Petunia & Allium & Albarte & \\
\hline $94,500 \mathrm{Da}$ & $0.57^{\mathrm{b}}$ & $1.01^{\mathrm{a}}$ & $0.40^{\mathrm{C}}$ & $1.01^{\mathrm{a}}$ & $1.04^{\mathrm{a}}$ & $0.97^{\mathrm{a}}$ & 0.124 \\
\hline $89,500 \mathrm{Da}$ & $0.15^{\mathrm{e}}$ & $0.66^{\mathrm{C}}$ & $0.26^{\mathrm{d}}$ & $0.95^{\mathrm{b}}$ & $1.56^{\mathrm{a}}$ & $0.67^{\mathrm{C}}$ & 0.047 \\
\hline $66,970 \mathrm{Da}$ & $1.11^{\mathrm{c}}$ & $1.63^{\mathrm{a}}$ & $1.29^{\mathrm{b}}$ & $0.72^{f}$ & $0.97^{d}$ & $0.88^{e}$ & 0.081 \\
\hline $58,850-63,300 \mathrm{Da}$ & $1.71^{\mathrm{e}}$ & $2.22^{b c}$ & $2.92^{\mathrm{a}}$ & $1.97^{d}$ & $2.38^{\mathrm{b}}$ & $2.08^{\mathrm{cd}}$ & 0.235 \\
\hline $49,800-54,800 \mathrm{Da}$ & $3.61^{a b}$ & $3.22^{\mathrm{cd}}$ & $3.77^{\mathrm{a}}$ & $3.08^{d}$ & $3.41^{b c}$ & $3.30^{\mathrm{bcd}}$ & 0.300 \\
\hline $46,200 \mathrm{Da}$ & $3.08^{a}$ & $2.43^{\mathrm{C}}$ & $2.77^{\mathrm{b}}$ & $1.53^{\mathrm{e}}$ & $2.13^{\mathrm{cd}}$ & $2.26^{\mathrm{C}}$ & 0.271 \\
\hline \multirow[t]{3}{*}{$42,900 \mathrm{Da}$} & $0.58^{\mathrm{d}}$ & n.d. & $1.30^{b}$ & $1.54^{\mathrm{a}}$ & $1.39^{\mathrm{b}}$ & $1.12^{\mathrm{C}}$ & 0.110 \\
\hline & n.d. & $1.06^{\mathrm{a}}$ & $0.90^{\mathrm{b}}$ & $0.90^{\mathrm{b}}$ & $0.72^{\mathrm{C}}$ & $0.92^{b}$ & 0.047 \\
\hline & n.d. & $0.75^{\mathrm{a}}$ & $0.73^{\mathrm{ab}}$ & $0.77^{\mathrm{a}}$ & $0.63^{\mathrm{C}}$ & n.d. & 0.032 \\
\hline $36,800-38,180 \mathrm{Da}$ & $9.02^{\mathrm{a}}$ & $7.62^{d}$ & $8.19^{C}$ & $7.52^{d}$ & $8.82^{\mathrm{ab}}$ & $8.55^{\mathrm{b}}$ & 0.332 \\
\hline $35,300 \mathrm{Da}$ & $9.19^{b}$ & $7.34^{d}$ & $9.64^{\mathrm{a}}$ & $7.70^{d}$ & $7.54^{d}$ & $8.35^{\mathrm{C}}$ & 0.395 \\
\hline \multirow[t]{2}{*}{$33,800 \mathrm{Da}$} & $3.54^{\mathrm{cd}}$ & $2.96^{\mathrm{e}}$ & $3.24^{\mathrm{de}}$ & $3.77^{\mathrm{bc}}$ & $4.26^{\mathrm{a}}$ & $3.88^{\mathrm{b}}$ & 0.300 \\
\hline & n.d & $1.52^{\mathrm{a}}$ & $0.79^{C}$ & n.d. & n.d. & $0.94^{\mathrm{b}}$ & 0.039 \\
\hline $32,950 \mathrm{Da}$ & $3.20^{a}$ & $1.33^{\mathrm{d}}$ & $1.11^{\mathrm{e}}$ & $3.07^{\mathrm{ab}}$ & $3.00^{\mathrm{b}}$ & $2.35^{\mathrm{C}}$ & 0.176 \\
\hline \multirow[t]{2}{*}{$31,600 \mathrm{Da}$} & $8.74^{\mathrm{a}}$ & $8.29^{b}$ & $8.66^{\mathrm{ab}}$ & $7.13^{d}$ & $6.78^{d}$ & $7.72^{\mathrm{C}}$ & 0.417 \\
\hline & $2.39^{a}$ & $1.98^{\mathrm{b}}$ & n.d. & $1.97^{\mathrm{b}}$ & $1.96^{\mathrm{b}}$ & n.d & 0.135 \\
\hline $29,600 \mathrm{Da}$ & $2.27^{\mathrm{C}}$ & $2.99^{b}$ & $3.26^{b}$ & $1.60^{\mathrm{d}}$ & n.d. & $3.67^{\mathrm{a}}$ & 0.369 \\
\hline $25,100-25,800 \mathrm{Da}$ & $15.89^{\mathrm{a}}$ & $14.00^{c}$ & $14.80^{\mathrm{b}}$ & $14.87^{b}$ & $11.39^{\mathrm{e}}$ & $12.72^{d}$ & 0.748 \\
\hline $23,600 \mathrm{Da}$ & $5.13^{\mathrm{a}}$ & $4.84^{\mathrm{a}}$ & $4.08^{b}$ & $3.96^{b}$ & $4.16^{\mathrm{b}}$ & $3.84^{b}$ & 0.565 \\
\hline \multirow[t]{2}{*}{$22,800 \mathrm{Da}$} & $5.54^{\mathrm{a}}$ & $5.00^{c}$ & $5.69^{\mathrm{a}}$ & $4.34^{d}$ & $4.23^{d}$ & $5.23^{b}$ & 0199 \\
\hline & $2.21^{b c}$ & $2.07^{\mathrm{C}}$ & $2.49^{\mathrm{a}}$ & $2.37^{\mathrm{ab}}$ & $2.48^{\mathrm{a}}$ & $2.07^{\mathrm{C}}$ & 0.188 \\
\hline \multirow[t]{3}{*}{$20,100 \mathrm{Da}$} & $6.88^{\mathrm{b}}$ & $6.32^{\mathrm{C}}$ & $6.05^{\mathrm{C}}$ & $6.83^{b}$ & $7.54^{\mathrm{a}}$ & $7.39^{\mathrm{a}}$ & 0.412 \\
\hline & n.d. & $1.32^{b}$ & $1.12^{\mathrm{c}}$ & $1.47^{\mathrm{a}}$ & $1.21^{\mathrm{C}}$ & $1.49^{\mathrm{a}}$ & 0.089 \\
\hline & $1.75^{\mathrm{d}}$ & $2.11^{\mathrm{b}}$ & $1.76^{\mathrm{d}}$ & $2.04^{b c}$ & $5.35^{\mathrm{a}}$ & $1.77^{\mathrm{cd}}$ & 0.289 \\
\hline $16,800 \mathrm{Da}$ & $2.24^{e}$ & $3.25^{\mathrm{cd}}$ & $3.12^{d}$ & $3.67^{c}$ & $7.97^{\mathrm{a}}$ & $4.64^{b}$ & 0.499 \\
\hline $14,800 \mathrm{Da}$ & $6.60^{c}$ & $7.57^{d}$ & $8.10^{b}$ & $8.31^{b}$ & $1.61^{\mathrm{e}}$ & $9.10^{\mathrm{a}}$ & 0.503 \\
\hline $11,500 \mathrm{Da}$ & $3.99^{\mathrm{ab}}$ & $3.68^{\mathrm{ab}}$ & $3.55^{b}$ & $4.14^{a}$ & $3.89^{a b}$ & $4.08^{\mathrm{a}}$ & 0.469 \\
\hline
\end{tabular}


To identify variants of storage proteins in sunflower seeds and kernels, protein extracts were analyzed by SDS-PAGE. Electrophoresis patterns of total proteins from the analyzed genotypes are shown in Figure 1. The content of total extracted proteins, determined by the Bradford (1976) method, was 7.49, 6.53, and $5.44 \mathrm{mg} /$ $\mathrm{ml}$ in the seeds and $10.04,7.62$, and $7.71 \mathrm{mg} / \mathrm{ml}$ in the kernels of the hybrids Es Petunija, Allium and Albatre, respectively. However, $25 \mu \mathrm{l}$ of the solution containing $50 \mu \mathrm{g}$ of protein were loaded per well. The quantification of the $11 \mathrm{~S}$ and $2 \mathrm{~S}$ fractions and the other detected polypeptides was done by densitometric analysis of the gel protein fraction (Table 2). The SDS-PAGE profiles of the seed and kernel proteins in the crude extracts for all the genotypes showed a very similar number of protein bands (thirty two) in the electrophoretograms (Figure 1). The highest molecular weight protein observed in the seed and kernel was 94,500 Da and the lowest $11,500 \mathrm{Da}$. Jiang et al. (1994) reported that sunflower proteins showed bands at 21,000-57,000 Da.

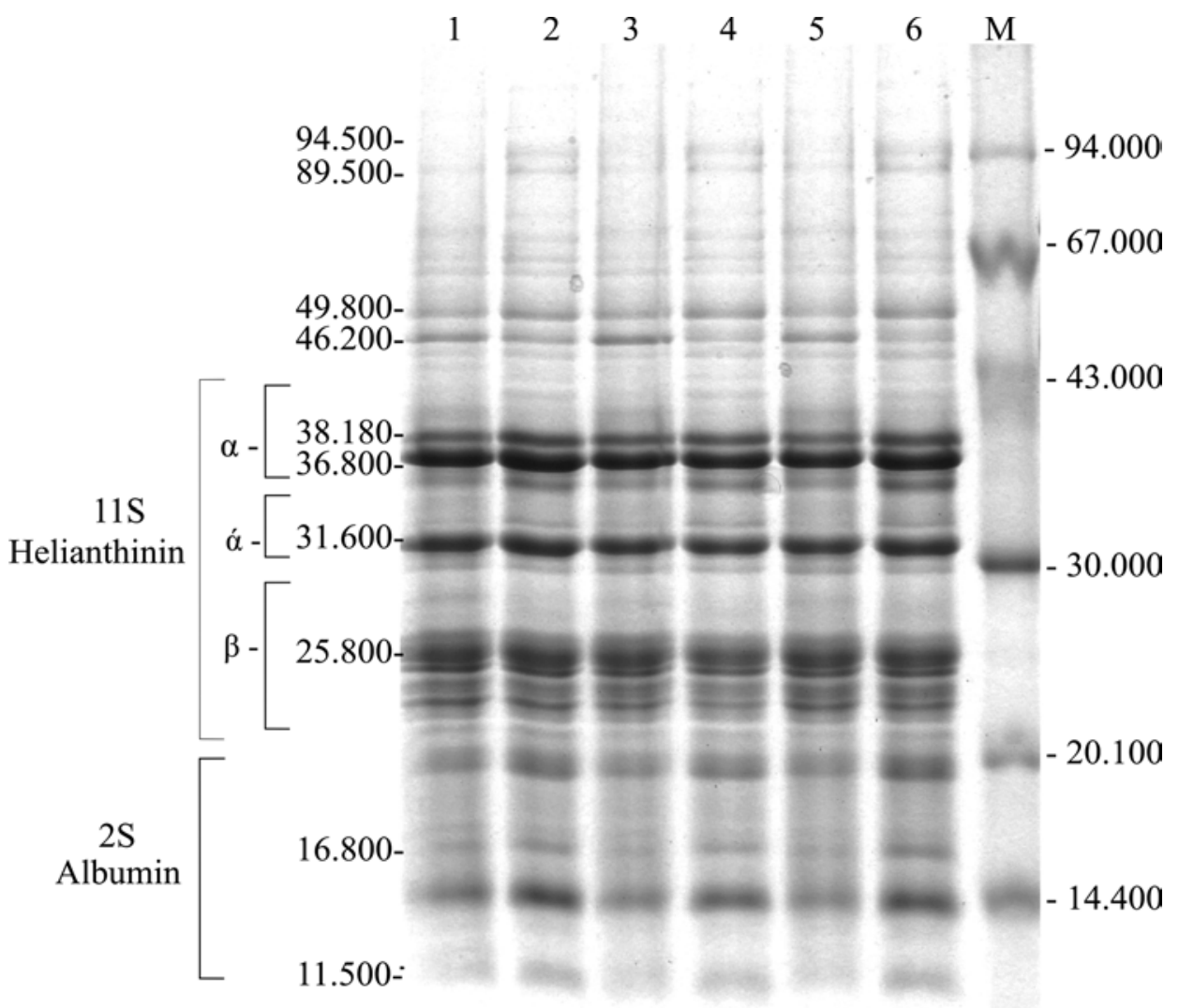

Figure 1: SDS-PAGE patterns of proteins from sunflower hybrids. $\alpha, \alpha$ and $\beta$ indicate acidic and basic polypeptides of $11 \mathrm{~S}$ helianthinin, respectively.

1-Albatre (seed), 2-Albatre (kernel), 3-Es Petunija (seed), 4-Es Petunija (kernel), 5-Allium (seed), 6-Allium (kernel), M-molecular weight standards 
A treatment with the reduction agent $\beta$-mercaptoethanol induced dissociation of the helianthinin fraction to polypeptides whose spectrum included three groups of components, two of which were acidic $\left(\alpha, \mathrm{Mw}=36,800-42,900 \mathrm{Da}\right.$ and $\alpha^{\prime}$, $\mathrm{Mw}=31,000-35,300 \mathrm{Da})$ and one basic $(\beta, \mathrm{Mw}=21,000-29,600 \mathrm{Da})$ (Figure 1). The results of Anisimova et al. (2004) showed that the standard helianthinin spectrum included eight to ten major components and a number of minor variants. Association and dissociation phenomena are a common feature of many $11 \mathrm{~S}$ seed globulins (Marcone, 1999). Like other 11S seed globulins, helianthinin seems to dissociate into subunits according to the following scheme: $11 \mathrm{~S} \rightarrow 7 \mathrm{~S} \rightarrow 3-2 \mathrm{~S}$ (González-Pérez et al., 2004). The molecular weight of the $2 \mathrm{~S}$ albumin proteins ranged from 11,500 to 20,100 Da (Figure 1). According to Kortt et al. (1991) the sunflower 2S protein fraction contains at least eight distinct proteins, and two of these are sulfur-rich with $8 \%$ of residues cysteine and $16 \%$ methionine.

Besides major protein subunits, polypeptides with molecular weight $94.5 \mathrm{kDa}$, $89.5 \mathrm{kDa}, 66.97 \mathrm{kDa}, 58.85$ to $63.3 \mathrm{kDa}, 49.8$ to $54.8 \mathrm{kDa}$ and $46.2 \mathrm{kDa}$ were detected by SDS-PAGE in all analyzed samples. These polypeptides could be a result of partial helianthinin dissociation (Figure 1, Table 2).

According to our results, there were significant differences among the seed and kernel protein contents. In our study, the $2 \mathrm{~S}$ albumin content was significantly higher in kernels than in seeds of sunflower hybrids $(\mathrm{P}<0.05)$. The kernels of Albatre had the highest content of $2 \mathrm{~S}$ protein $(28.48 \%$ of the total extracted protein) by a significant margin. In the seed, the $2 \mathrm{~S}$ content ranged from 21.46 to $24.50 \%$ of the total extracted proteins (Table 3). In all analyzed samples, the content of $11 \mathrm{~S}$ protein was more than two times higher than that of $2 \mathrm{~S}$ protein. In contrast with $2 \mathrm{~S}$ albumin, 11S helianthinin content was significantly higher in seeds than in kernels of the sunflower hybrids $(\mathrm{P}<0.05)$. The $11 \mathrm{~S}$ content ranged from 61.75 to $67.70 \%$ of the total extracted proteins in the seeds and from 57.36 to $61.51 \%$ in the kernels of the hybrids. Also, the content of total acid and basic subunits of helianthinin was significantly higher in the seeds than in the kernels of the hybrids $(\mathrm{P}<0.05)$. Among the detected proteins, acidic ( $\alpha+\alpha)$ subunits of $11 \mathrm{~S}$ protein were dominant and ranged from 32.85 to $36.66 \%$ of the total extracted proteins in the seeds and from 33.83 to $35.10 \%$ in the kernels of the hybrids. Of particular note was hybrid Allium, which had a significantly higher content of acid $(\alpha+\alpha)$ subunit in the kernel than in the whole seed (35.10\% of total extracted proteins, as opposed to $32.85 \%$ ) $(\mathrm{P}<0.05)$. Also, this genotype had the lowest content of basic $(\beta)$ subunit of helianthinin in the kernel (22.26\% of total extracted proteins) (Table 3).

Variations were found in the mean protein ratio of $11 \mathrm{~S}$ and $2 \mathrm{~S}$ proteins among the seeds and kernels of the hybrids under study. The ratio of $11 \mathrm{~S} / 2 \mathrm{~S}$ proteins varied from 2.08 to 3.15 among the genotypes (Table 3). According to Mazhar et al. (1998), the mean $11 \mathrm{~S}$ helianthinin to $2 \mathrm{~S}$ albumin ratio was $2: 1$. This ratio is known to influence the protein quality of sunflower and greatly affects the functional properties of food products made from sunflower (González-Pérez et al., 2005). Kortt et 
al. (1991) reported that the sunflower 2S proteins are resistant to degradation by rumen bacteria. This indicates that these sulfur-rich proteins may be ideal candidates for improving the nutritive content (with respect to the sulfur amino acids) of the seed and vegetative tissue of plants destined for ruminant feeding. However, sunflower seed has been responsible for serious anaphylactic reactions in some allergic individuals. The nature of the major allergen remains unknown, but some IgE-binding proteins have been identified, including the $2 \mathrm{~S}$ methionine-rich albumin protein (SSA). Preliminary findings indicated the possibility that SSA possesses linear epitopes (Kelly and Hefle, 2000). The globulins (helianthinin) have typically been obtained as a secondary by-product from the processing of the seed. The protein isolates in human foods continue to be used as a meat substitute in products such as hamburgers and sausages and have also been used as whipping agents, emulsifiers and binding agents in a variety of food products such as bakery products and dairy analogues in order to replace more expensive animal-based protein ingredients derived from eggs and milk (Fukushima, 1991).

Table 3: Concentration of $2 \mathrm{~S}$ and $11 \mathrm{~S}$ fractions in seed and kernel of sunflower hybrids (\% per total soluble proteins)

\begin{tabular}{|c|c|c|c|c|c|c|c|}
\hline \multirow{2}{*}{ Polypeptides } & \multicolumn{3}{|c|}{ Whole seed } & \multicolumn{3}{|c|}{ Kernel } & \multirow{2}{*}{$\mathrm{LSD}_{0.05}$} \\
\hline & Es Petunia & Allium & Albarte & Es Petunia & Allium & Albarte & \\
\hline Total 2S (Albumin) & $21.46^{\dagger}$ & $24.25^{d}$ & $23.70^{\mathrm{e}}$ & $26.46^{\mathrm{C}}$ & $27.54^{b}$ & $28.47^{\mathrm{a}}$ & 0.248 \\
\hline Total 11S (Helianthinin) & $67.70^{\mathrm{a}}$ & $61.75^{\mathrm{C}}$ & $64.88^{b}$ & $61.51^{\mathrm{c}}$ & $57.36^{d}$ & $61.36^{\mathrm{C}}$ & 0.427 \\
\hline $\begin{array}{l}\text { Total acid subunit of } \\
\text { helianthinin }\left(\alpha+\alpha^{\prime}\right)\end{array}$ & $36.66^{\mathrm{a}}$ & $32.85^{\mathrm{e}}$ & $34.56^{\mathrm{C}}$ & $34.37^{\mathrm{C}}$ & $35.10^{\mathrm{b}}$ & $33.83^{d}$ & 0.437 \\
\hline $\begin{array}{l}\text { Total basic subunit } \\
\text { of helianthinin }(\beta)\end{array}$ & $31.04^{a}$ & $28.90^{C}$ & $30.32^{b}$ & $27.14^{d}$ & $22.26^{\mathrm{e}}$ & $27.53^{d}$ & 0.395 \\
\hline $11 \mathrm{~S} / 2 \mathrm{~S}$ ratio & $3.15^{\mathrm{a}}$ & $2.55^{\mathrm{C}}$ & $2.74^{b}$ & $2.32^{\mathrm{d}}$ & $2.08^{\mathrm{e}}$ & $2.15^{\mathrm{e}}$ & 0.141 \\
\hline
\end{tabular}

There is not much data in the literature on the content of sunflower protein fractions, so it was difficult to compare our results. Different problems arose during the isolation and purification step of the major protein fraction of sunflower seeds (Durante et al., 1989). One of the reasons was the presence of relatively high amounts of phenolic compounds, especially chlorogenic acid. Phenolic compounds interact and form complexes with proteins, thereby reducing both their digestibility and their functionality (Sastry and Rao, 1990). Many methods have been proposed for isolating sunflower protein and removing phenolic compounds from sunflower seeds. Also, one of the main factors that has complicated the purification and characterization of globulins (helianthinin) is that they are known to dissociate with very small shifts in $\mathrm{pH}$ (Wright, 1987). It therefore appears that $\mathrm{pH}$ dependent dissociation of globulins is a common physicochemical characteristic.

Our data provide increased knowledge of the sunflower proteins. 


\section{CONCLUSION}

Currently, limited information is available on the biochemical and genetic mechanisms that regulate high-proteins. Essentially, two avenues of improving sunflower protein have to be utilized. The first is through traditional breeding using high-protein germplasm and the second is the use of biotechnology.

The results showed that the protein bands were similar among all the sunflower samples. Three polypeptides groups of helianthinin fraction were detected. Two of these were acidic $\left(\alpha, \mathrm{Mw}=36,800-42,900 \mathrm{Da}\right.$ and $\left.\alpha^{\prime}, \mathrm{Mw}=31,000-35,300 \mathrm{Da}\right)$, while one was basic $(\beta, \mathrm{Mw}=21,000-29,600 \mathrm{Da})$. The molecular weight of the $2 \mathrm{~S}$ albumin proteins ranged from 11,500 to 20,100 Da.

However, the contents of $2 \mathrm{~S}$ and $11 \mathrm{~S}$ proteins were statistically different among the sunflower hybrids as well as among the seeds and kernels of sunflower. The $2 \mathrm{~S}$ albumin content was significantly higher in kernels than in seeds of sunflower hybrids. In contrast, the 11S helianthinin content was significantly higher in seeds than in kernels of the hybrids.

The highest content of $2 \mathrm{~S}$ albumin was found in the kernel of the hybrid Albatre, while the highest content of 11S helianthinin was observed in the seed of the hybrid Es Petunija. The latter sample had the highest content of acid and basic subunits of $11 \mathrm{~S}$ helianthinin.

Our data provide increased knowledge of the variability of protein and protein subunit accumulation among Serbian hybrids, which will facilitate ongoing efforts to improve both the quantity and quality of sunflower protein.

\section{REFERENCES}

Anisimova, I.N. and Gavrilyuk., I.P., 1990. Heterogeneity and polymorphism of $11 \mathrm{~S}$ globulin in sunflower seeds. Sov. Genet. 25: 811-815.

Anisimova, I.N., Gavrilova, V.A., Loskutov, A.V., Rozhkova, V.T. and Tolmachev, V.V., 2004. Polymorphism and inheritance of seed storage protein in Sunflower. Plant Genetics 40(9): 1215-1223.

Bradford, M.M., 1976. A rapid and sensitive method for quantization of microgram quantities of protein utilizing the principle of protein-dye-binding. Anal. Biochem. 72: 248-254.

Canibe, N., Pedrosa, M.M., Robredo, L.M. and Knudsen, K.E.B., 1999. Chemical composition, digestibility and protein quality of 12 sunflower (Helianthus annuus L.) cultivars. J. Sci. Food Chem. 79: 1775-1782.

Dalgalarrondo, M., Raymond, J. and Azanza, J.L., 1984. Sunflower seed proteins: characterization and subunit composition of the globulin fraction. J. Exp. Bot. 35: 1618-1628.

Dorrell, D.G. and Vick, B.A., 1997. Properties and processing of oilseed sunflower. In: Schneiter, A.A. (Eds), Sunflower technology and production American Society of Agronomy, Madison, Wisconsin, pp. 709-744.

Durante, M., Bernardi, R., Lupi, M.C. and Sabelli, P.A., 1989. Characterization of Helianthus annuus L. storage proteins. J. Agric. Food Chem. 37: 852-855.

Fling, S.P. and Gregerson, D.S., 1986. Peptide and protein molecular weight determination by electrophoresis using a high-molarity Tris-buffer system without urea. Anal. Biochem. 155: 83-88.

Fukushima, D., 1991. Structures of plant storage proteins and their function. Food Reviews International 7(3): 353-381.

González-Pérez, S. and Vereijken, J.M., 2007. Sunflower proteins: overview of their physicochemical, structural and functional properties. J. Sci. Food Agric. 87: 2173-2191. 
González-Pérez, S., van Koningsveld, G.A., Vereijken, J.M., Merck, K.B., Gruppen, H. and Voragen, A.G.J., 2005. Emulsion properties of sunflower (Helianthus annuus L.) proteins. J. Agric. Food Chem. 53: 2261-2267.

González-Pérez, S., Vereijken, J.M., Merck, K.B., van Koningsveld, G.A., Gruppen, H. and Voragen, A.G.J., 2004. Conformational states of sunflower (Helianthus annuus L.) helianthinin: Effect of heat and pH. J. Agric. Food Chem. 52: 6770-6778.

Guéguen, J., Chevalier, M., Barbot, J. and Schaeffer, F., 1988. Dissociation and aggregation of pea legumin induced by $\mathrm{pH}$ and ionic strength. J. Sci. Food Agric. 44: 167-182.

Jiang, L.W., Bunkelmann, J., Towill, L., Kleff, S. and Trelease, N., 1994. Identification of peroxisome membrane proteins (PMPs) in sunflower (Helianthus annuus L.) cotyledons and influence of light on the PMP developmental pattern. Plant Physiol. 106: 293-302.

Kabirullah, M. and Wills, R.B.H., 1983. Characterization of sunflower protein. J. Agric. Food Chem. 31: 953-956.

Kelly, J.D. and Hefle, S.L., 2000. IgE-binding epitopes in the 2S methionine-rich albumin (SSA) of sunflower seed. J. Allergy Clin. Imunol. 105: S135.

Korhonen, H. and Pihlanto, A., 2006. Bioactive peptides: production and functionality. International Dairy Journal 16: 945-960.

Kortt, A.A. and Caldwell, J.B., 1990. Low molecular weight albumins from sunflower seed: identification of a methionine-rich albumin. Phytochemistry 29: 2805-2818.

Kortt, A.A., Caldwell, J.B., Lilley, G.G. and Higgins, T.J.V., 1991. Amino acid and cDNA sequences of a methionine-rich $2 \mathrm{~S}$ protein from sunflower seed (Helianthus annuus L.). Eur. J. Biochem. 195: 329-334.

Landry, J. and Moureaux, T., 1970. Heterogeneity of the glutelins of the grain corn. Selective extraction and composition in amino acids of the three isolated fractions. Bull. Soc. Chim. Bio. 52: 1021-1037.

Marcone, M.F., 1999. Biochemical and biophysical properties of plant storage proteins: a current understanding with emphasis on 11S seed globulins. Food Res. Int. 32: 79-92.

Mazhar, H., Quayle, R., Fido, R.J., Stobart, A.K., Napier, J.A. and Shewry, P.R., 1998. Synthesis of storage reserves in developing seeds of sunflower. Phytochemistry 48(3): 429-432.

Megías, C., Pedroche, J., Yust, M.M., Girón-Calle, J., Alaiz, M., Millán, F. and Vioque, J., 2008. Production of copper-chelating peptides after hydrolysis of sunflower proteins with pepsin and pancreatin. Food Science and Technology 41(10): 1973-1977.

Molina, E.A., Papadopulou, A. and Ledward, D.A., 2001. Emulsifyting properties of high pressure treated soy protein isolate and $7 \mathrm{~S}$ and $11 \mathrm{~S}$ globulins. Food Hydrocolloids 15 : 263-269.

Pandya, M.J., Sessions, R.B., Williams, P.B., Dempsey, C.E., Tatham, A.S., Shewry, P.R., 2000. Structural characterization of a methionine-rich, emulsifying protein from sunflower seed. Protein Struct. Funct. Genet. 38: 341-349.

Plietz, P., Damaschun, G., Muller, J.J. and Schwenke, K.D., 1983. The structure of 11-S globulins from sunflower and rape seed. A small-angle X-ray scattering study. Eur. J. Biochem. 22: 315-320.

Ross, J.H.E. and Murphy, D.J., 1992. Biosynthesis and localisation of storage proteins, oleosins and lipids during seed development in Coriandrum sativum and other Umbelliferae. Plant Sci. 86: 59-64.

Sastry, M.C.S. and Rao, M.S.N., 1090. Binding of chlorogenic acid by the isolated polyphenolfree 11S protein of sunflower (Helianthus annuus L.) seed. J. Agric. Food Chem. 38: 2103-2110.

Škorić, D., Jocić, S., Hladni, N. and Vannozzi, G.P., 2007. An analysis of heterotic potential for agronomically important traits in sunflower (Helianthus annuus L.). Helia 30(46): 55-74.

Thanh, V.H. and Shibasaki, K., 1976. Major proteins of soybean seeds. A straightforward fractionation and their characterization. J. Agric. Food Chem. 24: 1117-1121.

Villanueva, A., Vioque, J., Sánchez-Vioque, R., Clemente, A., Pedroche, J., Bautista, J. and Millán, F., 1999. Peptide characteristics of sunflower protein hydrolysates. Journal of the American Oil Chemists Society 76: 1455-1460.

Wright, D.J., 1987. The seed globulins. In: Hudson, B.J.F. (Ed.), Development in food proteins. Vol. 5, London, Elsevier Applied Science pp. 81-157.

Youle, R.J. and Huang, A.H.C., 1981. Occurrence of low molecular weight and high cysteine containing albumin storage proteins in oilseeds of diverse species. American Journal of Botany 68: 44-48. 